\title{
Neuropsychiatric effects of low exposure to styrene
}

\author{
U FLODIN, K EKBERG, L ANDERSSON \\ From the Department of Occupational Medicine, University Hospital, Linköping, Sweden
}

\begin{abstract}
Workers exposed to styrene concentrations of about $50 \mathrm{mg} / \mathrm{m}^{3}$ at a plant manufacturing reinforced polyester boats were examined for neuropsychiatric symptoms both in close connection with exposure and also seven months after exposure had ceased. Physical workload is important for the uptake of styrene and was about $50 \mathrm{~W}$ at this plant. On the first occasion, after one week with no exposure, the workers reported a high frequency of neuropsychiatric symptoms such as fatigue, irritation, and forgetfulness whereas seven months later the frequency of these symptoms was low. These observations indicate that exposure to styrene at about $50 \mathrm{mg} / \mathrm{m}^{3}$ may induce reversible neuraesthenic symptoms. Even the relatively low Swedish standard $\left(110 \mathrm{mg} / \mathrm{m}^{3}=25 \mathrm{ppm}\right) \mathrm{may}$, therefore, need revising.
\end{abstract}

Styrene is taken up mainly through the lungs and is readily soluble in the blood. ${ }^{1}$ It is toxic to the central nervous system and symptoms of fatigue, difficulty with concentration, and irritation have been reported. ${ }^{2}$ Symptoms such as nausea, dizziness, and feeling drunk during the workday were reported in an exposed group with a mean mandelic acid excretion of about $800 \mathrm{mg} / 1(5.3 \mathrm{mmol} / \mathrm{l}){ }^{2}$ corresponding to a concentration of styrene of about $160 \mathrm{mg} / \mathrm{m}^{3}$ in the air. $^{3}$

Workers exposed to styrene have prolonged reaction times at the end of the workshift when the mean concentration of styrene in the breathing zone has been rather high, about $150 \mathrm{ppm}\left(650 \mathrm{mg} / \mathrm{m}^{3}\right)^{4}$ and 92 ppm $\left(400 \mathrm{mg} / \mathrm{m}^{3}\right),{ }^{5}$ but effects from a much lower concentration, $17 \mathrm{ppm}\left(75 \mathrm{mg} / \mathrm{m}^{3}\right)$, have also been reported. ${ }^{6}$ These reported concentrations are mean values of exposure concentrations with wide ranges, which makes it difficult to find a concentration where no acute effect could be seen. Nevertheless, Edling and Ekberg did not find any symptoms of neuraesthenia in a group of workers who were exposed to a mean concentration of about $50 \mathrm{mg} / \mathrm{m}^{3}$.

Abnormal EEG frequencies have been reported more frequently in groups exposed to styrene, excreting more than $4.6 \mathrm{mmol} / \mathrm{l}$ of mandelic acid (corresponding to more than $130 \mathrm{mg} / \mathrm{m}^{3}$ of styrene). ${ }^{3}$ At about $5 \cdot 3$ $\mathrm{mmol} / \mathrm{l}$ of mandelic acid (corresponding to about 170 $\mathrm{mg} / \mathrm{m}^{3}$ styrene in the air) visuomotor performance was impaired. ${ }^{3}$ Verbal learning skills were significantly impaired in workers exposed to concentrations of

Accepted 19 December 1988 styrene over $25 \mathrm{ppm}\left(110 \mathrm{mg} / \mathrm{m}^{3}\right)$ as a mean daily exposure. $^{8}$

Styrene remains in detectable concentrations $(0 \cdot 1$ $\mathrm{mg} / \mathrm{kg}$ ) in adipose tissue for up to five weeks after a single exposure of two hours to $50 \mathrm{ppm}$. $^{1}$ We have no information about the residence time of styrene in cerebral tissue.

The present study was carried out to determine if daily exposure to low concentrations of styrene (about $50 \mathrm{mg} / \mathrm{m}^{3}$ ) would cause neuropsychiatric and behavioural symptoms after a comparably short (one week) and a longer (several months) period with no exposure.

Workers at a plant manufacturing reinforced polyester boats were examined twice. On the first occasion we examined 21 workers when they had not been exposed for one week in order to eliminate acute effects. Of these, 19 were seen a second time; two were not willing to take part. At the second examination the subjects had not been exposed for some seven months because the factory has gone bankrupt. This gave an opportunity to compare each individual with himself after being unexposed for a prolonged period.

\section{Material}

The 21 men, mean age 37 (range 28-61) including all but three (who had refused) who were employed at the plant were admitted for examination at our occupational medicine clinic. Many complained of tiredness and dizziness, headache, and other symptoms suspected of being caused by exposure to styrene. They had been employed in solvent exposed work for between six and 21 years (mean 11.6). They were all men of Swedish origin. 


\section{Methods}

\section{ASSESSMENT OF EXPOSURE}

The group of 21 men was divided into a high exposed and a low exposed group based on the available exposure information. Those in the high exposed group had worked on spraying the styrene-polyester mixture, rolling, and other tasks in the context of lamination. All in this group had been actively handling styrene for several hours each day. The subjects in the low exposed group had tasks with comparably short or no periods of handling styrene each day but they were intermittently working in the same hall as the high exposed group with tasks such as assembling boats.

Measurements of airborne styrene had been performed during 1976-87, except for 1978, 1984, and 1986. The airborne measurements were performed on tasks in the high exposed group. Figure 1 shows airborne concentrations at three types of tasks. The high exposed subjects had been exposed to about $50 \mathrm{mg} / \mathrm{m}^{3}$ styrene since 1981 whereas the low exposed subjects are estimated to have been exposed to concentrations below $25 \mathrm{mg} / \mathrm{m}^{3}$ (current Swedish TLV $1988=$

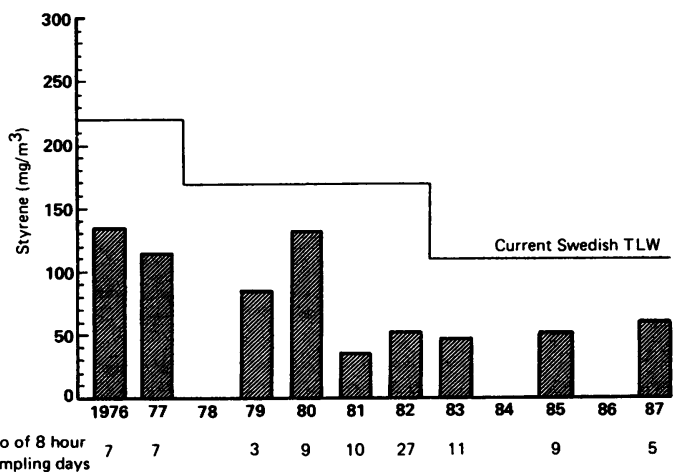

Fig 1 Air concentrations of styrene $\left(\mathrm{mg} / \mathrm{m}^{3}\right)$, personal sampling, eight hour average concentrations. Samples of 1976-87 at gelcoating, spraying/rolling, and laminating.

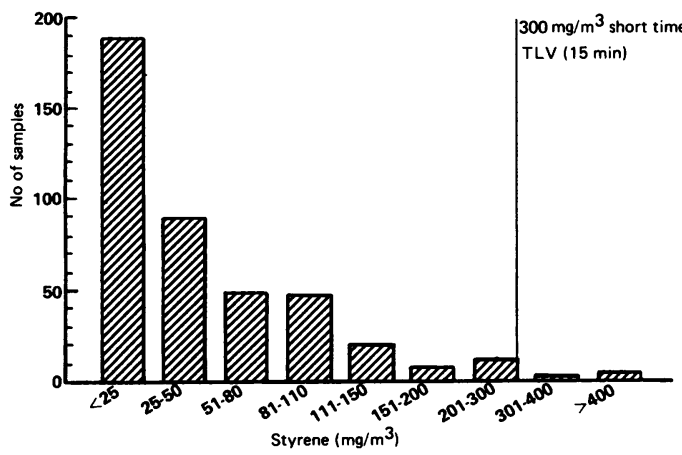

Fig 2 Distribution of samples of styrene concentration in air $\left(\mathrm{mg} / \mathrm{m}^{3}\right), 30$ minute samples $(n=417)$. Measurements performed in 1982. $\left.110 \mathrm{mg} / \mathrm{m}^{3}\right)$. In 1982 short time measurements were performed on most tasks and showed that peak exposures above the Swedish short time (15 min) TLV (currently $300 \mathrm{mg} / \mathrm{m}^{3}$ ) were exceptional (about $1 \%$ of all measurements) (fig 2).

Active sampling of airborne styrene was made with a Sipin pump and charcoal tubes. The tubes were placed in the breathing zone of the men and changed after 15 minutes to two hours. Analyses of the charcoal tubes were made with conventional technique with desorbtion with carbon disulphide and gas chromatography analysis. ${ }^{9}$

\section{EXAMINATIONS}

The workers were first examined in the autumn of 1985 by a clinical interview and a detailed inquiry of neuropsychiatric symptoms, using questionnaire $16 .^{10}$ This includes questions on abnormal fatigue, deterioration of memory, personality changes of aggressive or depressive type, frequency of headache, and changes in sexual interest. The questionnaire also covers questions on painful tingling in any parts of the body, heart palpitations, oppression in the chest, and perspiration. A psychometric examination with the TUFF battery comprising tests on verbal ability, cognitive functions, perceptual speed and accuracy, manual dexterity, learning, and memory ability was performed on all subjects."

The following clinical chemical laboratory testo were also performed on all subjects: serum; bilirubit direct and total, alkaline phosphatase, aminotranso ferases, lactic dehydrogenase, glutamyltransferase, creatinine, and total proteins.

In November 1986 the subjects were reexamined when they had been free from exposure to styrene for some months. This second examination comprised a clinical interview and the detailed inquiry about neuropsychiatric symptoms, again using questionnaire $16 .{ }^{10} \mathrm{~T}$ wo subjects were not willing to participate in the reexamination. One had had a pulmonary thrombosis after the first examination and was excluded from the reexamination. The other was excluded from the high exposed group as he had been given a diagnosis or psycho-organic syndrome at the first examination and therefore by definition his condition was expected to be unchanged at the second examination. Thus 17 subjects were included in the second analysis.

\section{Results}

\section{FIRST EXAMINATION}

\section{Symptoms}

The dominating symptoms in the entire group of 21 subjects were abnormal tiredness and forgetfulness. Especially in the high exposed group headache, irritation, and complaints of a short memory and a need to go back and check things were common. The same 
Table 1 Results of questionnaire 16 among workers exposed to high and low intensity styrene

\begin{tabular}{|c|c|c|c|c|}
\hline \multirow[b]{3}{*}{ Questions/symptoms } & \multicolumn{4}{|c|}{ No of workers with symptoms } \\
\hline & \multicolumn{2}{|c|}{ High exposed group $(n=9)$} & \multicolumn{2}{|c|}{ Low exposed group $(n=8)$} \\
\hline & Ist examination & 2nd examination & 1st examination & 2nd examination \\
\hline $\begin{array}{l}1 \text { Are you abnormally tired? } \\
2 \text { Do you have palpitations of the heart even when you } \\
\text { don't exert yourself? }\end{array}$ & $\begin{array}{l}9 \\
4\end{array}$ & $\begin{array}{l}0 \\
0\end{array}$ & $\begin{array}{l}5 \\
2\end{array}$ & $\begin{array}{l}0 \\
1\end{array}$ \\
\hline $\begin{array}{l}3 \text { Do you often have painful tingling in some part of your } \\
\text { body? }\end{array}$ & 7 & 1 & 3 & 2 \\
\hline $\begin{array}{l}4 \text { Do you often feel irritated without any particular } \\
\text { reason? }\end{array}$ & 8 & 1 & 3 & 1 \\
\hline $\begin{array}{l}5 \text { Do you often feel depressed without any particular } \\
\text { reason? }\end{array}$ & 4 & 0 & 3 & $\mathbf{0}$ \\
\hline $\begin{array}{l}6 \text { Do you often have problems with concentrating? } \\
7 \text { Do you have a short memory? } \\
8 \text { Do you often perspire without any particular reason? } \\
9 \text { Do you have any problems with buttoning and } \\
\text { unbuttoning? }\end{array}$ & $\begin{array}{l}7 \\
9 \\
3 \\
0\end{array}$ & $\begin{array}{l}2 \\
2 \\
3 \\
1\end{array}$ & $\begin{array}{l}3 \\
8 \\
1 \\
0\end{array}$ & $\begin{array}{l}0 \\
2 \\
0 \\
0\end{array}$ \\
\hline $\begin{array}{l}10 \text { Do you generally find it hard to get the meaning from } \\
\text { reading newspapers and books? }\end{array}$ & 7 & 0 & 1 & $\mathbf{0}$ \\
\hline $\begin{array}{l}11 \text { Have your relatives told you that you have a short } \\
\text { memory? }\end{array}$ & 8 & 0 & 3 & 2 \\
\hline $\begin{array}{l}12 \text { Do you sometimes feel an oppression in your chest? } \\
13 \text { Do you often have to make notes about what you must }\end{array}$ & $\begin{array}{l}6 \\
6\end{array}$ & $\begin{array}{l}0 \\
1\end{array}$ & 1 & 1 \\
\hline $\begin{array}{l}14 \text { Do you often have to go back and check things you have } \\
\text { done such as turned off the stove, locked the door? }\end{array}$ & 8 & 4 & 3 & 4 \\
\hline $\begin{array}{l}15 \text { Do you have a headache at least once a week? } \\
16 \text { Are you less interested in sex than what you think is } \\
\text { normal? }\end{array}$ & $\begin{array}{l}8 \\
2\end{array}$ & $\begin{array}{l}1 \\
1\end{array}$ & $\begin{array}{l}3 \\
0\end{array}$ & $\begin{array}{l}1 \\
0\end{array}$ \\
\hline Mean & $10 \cdot 4$ & 1.9 & $5 \cdot 3$ & 1.9 \\
\hline
\end{tabular}

symptoms were less frequent in the low intensity exposed group (table 1).

\section{Psychometrical investigation}

Each subject's performance in the psychometrical tests was transformed into standardised scores ${ }^{11}$ to control for the influence of age.

Table 2 shows the performance of the group. The verbal performance is slightly inferior to the performance in the other tests, a pattern that probably reflects less extensive reading habits. The results in the remaining test are all at a level close to the mean of an unexposed reference group, ${ }^{11}$ and within a normal range.

One subject had an abnormal test profile and one a

Table 2 Mean performance in psychometrical tests in 21 workers exposed to high and low intensity styrene, expressed in standardised scores $(m=5,0, S D=2 \cdot 0)$

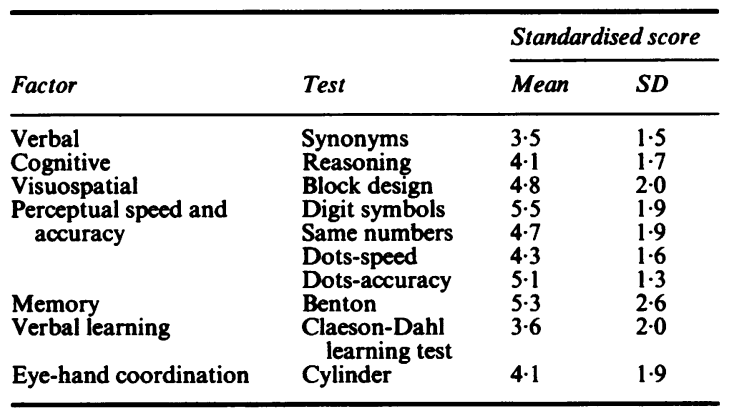

slight performance impairment: the remaining subjects all had normal test profiles.

The two subgroups were compared in performance in psychometrical tests. The high exposed group performed significantly worse in the manual dexterity cylinder test (high exposed: $\mathrm{m}=3 \cdot 3, \mathrm{SD}=1 \cdot 8$, low exposed: $\mathrm{m}=5.4, \mathrm{SD}=1.7, \mathrm{t}=2.4, \mathrm{p}<0.01$ ), whereas the groups did not differ in performance in the remaining tests.

\section{Diagnoses}

At the first examination one of the 21 subjects was diagnosed as having a psycho-organic syndrome. The requirement for the diagnosis is ${ }^{12}$ :

(1) Long and intense exposure to solvents for at least ten years,

(2) Relevant symptoms (described above),

(3) Presence of pathological findings in terms of an objective measure such as psychological function tests.

Five subjects were diagnosed as having a neuraesthenic syndrome due to exposure to solvents with abnormal fatigue as a dominant symptom.

Special interest was paid to exclude the following diseases among the group of patients: sequelae after traumatic head injury, diabetic coma-insulin coma, meningitis, asphyxia, presenile dementia, alcohol abuse, and psychiatric disorders. None of these diseases was diagnosed.

The clinical laboratory test results were generally normal. Minor aberations were seen for S-gamma-GT 
with slightly increased activity, at most $1.7 \mu \mathrm{cat} / 1$ (normally less than 0.7 ) in three of 21 patients. Serum aminotransferasis were slightly raised in three, at most $1.49 \mu \mathrm{cat} / 1$ (normally less than 0.7 ).

\section{SECOND EXAMINATION}

At the second examination the subjective well being of all had greatly improved, except for one who at the first examination had been diagnosed as having a psycho-organic syndrome. The improvement was subjectively detected after three to six months, according to most workers' own estimation.

In the high exposed group of nine subjects (mean age 40.7 years, mean employment at the plant 11.4 years) the mean number of symptoms on the questionnaire was on the first occasion 10.4 and on the second 1.9. In this subgroup the exposure free interval was on average 7.4 months.

In the low intensity exposed group $(n=8)$ (mean age 38.3 years, mean employment at the plant 10 years) the mean value of the symptoms on the questionnaire was 5.3 on the first occasion and on the second 1.9 (table 1). The exposure free interval was on average nine months.

\section{Discussion}

In any epidemiological studies there are often difficulties in finding a relevant reference group. In this case the enforced unemployment of the workers after the bankruptcy of the factory offered an opportunity to use the workers as their own controls after they had been unexposed for several months. The major finding was that the symptoms of neuraesthenia faded away after three to six months of non-exposure. Despite exposure levels being below the eight hours TLV $\left(110 \mathrm{mg} / \mathrm{m}^{3}\right)$ and the short time (15 minutes) permissible value of $300 \mathrm{mg} / \mathrm{m}^{3}$, most of the workers suffered symptoms. Five subjects with solvent induced neuraesthenia were diagnosed at the first examination.

The results of this study are not consistent with those of Edling and Ekberg where no symptoms of neuraesthenia in a group of industrial workers exposed to styrene was found at an exposure concentration of $50 \mathrm{mg} / \mathrm{m}^{3}$. No peak values were reported from that plant. This difference, however, may be explained by the fact that the workers in the plant for manufacturing reinforced polyester boats had a greater physical effort than the workers described by Edling and Ekberg, who were merely supervising. ${ }^{7}$

The uptake of styrene during physical work is largely enhanced by an increased workload. ${ }^{13}$ The uptake of styrene at a workload of $50 \mathrm{~W}$ is more than double that at rest during constant air styrene concentrations (and at $100 \mathrm{~W}$ more than three times that at rest). The workload when manufacturing reinforced polyester boats has been estimated to be about $50 \mathrm{~W}$, corresponding to a breathing volume of $20 \mathrm{l} /$ minute. $^{9}$

The workers in this plant had experienced some closures and reorganisations of the plant during the $\overline{\bar{a}}$ years because of bankruptcy of different owners. At $z$ the time of the first examination the threat of closure $\stackrel{\mathbb{Q}}{\circ}$ was imminent. The influence of threatening unemployment can, however, hardly explain all the symptoms reported, since the symptoms reported had started long before this and they were more pro- $\frac{D}{0}$ nounced in the high than the low exposed group, $\frac{\bar{c}}{7}$ although all the workforce were experiencing the same $\mathbb{\nabla}$ threat of unemployment. Therefore exposure to styrene is the most likely explanation to the symptoms described. In conclusion, this means that exposure to $\vec{O}$ styrene concentrations of about $50 \mathrm{mg} / \mathrm{m}^{3}$ for eight $\vec{\overrightarrow{ }}$ hours a day with peaks of up to $300 \mathrm{mg} / \mathrm{m}^{3}$ during $15 \omega$ minutes periods at a workload of $50 \mathrm{~W}$ for some years $\bigcirc$ seem to give neuraesthenic symptoms in most $\stackrel{\mathbb{D}}{3}$ individuals and some symptoms may last for at least three to six months after exposure has ceased.

We thank Dr T Carsten of Övde who recognised this patient group and thereby initiated this study.

\section{References}

1 Engström J, Astrand I, Wigaeus E. Exposure to styrene in a polymerisation plant. Scand J Work Environ Health 1978:4:324-9.

2 Härkönen H. Relationship of symptoms to occupational styrene $\stackrel{\mathbb{D}}{-}$ exposure and to the findings of electroencephalographic and $\vec{C}$ psychological examinations. Int Arch Occup Environ Heałh 1977;40:231-9.

3 Härkönen H, Lindström K, Seppälainen AM, Asp S, Hernberg Exposure-response relationship between styrene exposure a\#t central nervous function. Scand J Environ Health 1978;4:53-9.

4 Götell P, Axelson O, Lindelöf B. Fields studies on human styrene exposure. Work Environ Health 1972;9:76-83.

5 Cherry N, Waldron HA, Wells GG, Wilkinson RT, Wilson HK, 을 Jones S. An investigation of the acute behavioural effects of styrene on factory workers. $\mathrm{Br} J$ Ind Med 1980;37:234-40.

6 Gamberale F, Lisper HO, Anshelm-Olson B.The effect of styrene vapour on the reaction time of workers in the plastic boat industry. Vol 2. Adverse effects of environmental chemicals and psychotropic drugs. Amsterdam: Elsevier, 1979:135-48.

7 Edling C, Ekberg K. No acute behavioural effects of exposure to styrene: a safe level of exposure? Br J Ind Med 1985;42:301-4.

8 Mutti A, Mazzucchi A, Rustichelli P, Frigeri G, Arfini G, Franchini I. Exposure-effect and exposure response relation- 음 ships between occupational exposure to styrene and neuropsy- 3 chological functions. Am J Ind Med 1984;5:275-86.

9 National Institute for Occupational Safety and Health. Manual of analytical methods. Vol 2. Styrene. 2nd ed. Cincinnati: Department of Health Education and Welfare, Public Health Service, 윽 Center for Disease Control, 1977.

10 Axelson O, Hogstedt C. On the health effects of solvents. In: Zenz $\frac{D}{O}$ C, ed. Occupational medicine. Principles and practical applications. Chicago-London: Year Book Medical Publishers, Inc, N 1988:775-84.

11 Ekberg K, Hane M. Test battery for investigating functional $N$ disorders - the TUFF-battery. In: Proceedings of the Nordic conference in clinical behavioural toxicology, Örebro, Sweden, $\omega$ 1982. Scand J Work Environ Health 1984;10:suppl 1.

12 Flodin U, Edling C, Axelson O. Clinical studies on psycho-organic syndromes among workers with exposure to solvents. Am J Ind Med 1984;5:287-95.

13 Åstrand I. Effects of physical exercise on uptake, distribution and elimination of vapors in man. In: Fisirova-Bergerova V, ed. Modelling of inhalation exposure to vapors: uptake, distribution and elimination. Vol 2. Boca Raton; CRC Press, 1983. 